\title{
Charlotte Wilson, the "Woman Question", and the Meanings of Anarchist Socialism in Late Victorian Radicalism
}

\author{
SUSAN HINELY \\ Department of History, State University of New York \\ at Stony Brook \\ E-mail: susan.hinely@stonybrook.edu
}

\begin{abstract}
SUMMARY: Recent literature on radical movements in the late nineteenth and early twentieth centuries has re-cast this period as a key stage of contemporary globalization, one in which ideological formulations and radical alliances were fluid and did not fall neatly into the categories traditionally assigned by political history. The following analysis of Charlotte Wilson's anarchist political ideas and activism in late Victorian Britain is an intervention in this new historiography that both supports the thesis of global ideological heterogeneity and supplements it by revealing the challenge to sexual hierarchy that coursed through many of these radical crosscurrents. The unexpected alliances Wilson formed in pursuit of her understanding of anarchist socialism underscore the protean nature of radical politics but also show an over-arching consensus that united these disparate groups, a common vision of the socialist future in which the fundamental but oppositional values of self and society would merge. This consensus arguably allowed Wilson's gendered definition of anarchism to adapt to new terms as she and other socialist women pursued their radical vision as activists in the pre-war women's movement.
\end{abstract}

\section{INTRODUCTION}

London in the last decades of the nineteenth century was a global crossroads and political haven for a large number of radical activists and theorists, many of whom were identified with the anarchist school of socialist thought. In spite of the importance of London as a center of anarchist refuge and publication, native English anarchism in this period has usually been described as a marginal and idiosyncratic movement. ${ }^{\mathrm{I}}$

I. George Woodcock's history of anarchism, continuously in print since its initial publication in 1962, with revised editions available in several languages, and still the most widely cited source on the subject, presents this picture of native English anarchism; George Woodcock, Anarchism: A History of Libertarian Ideas and Movements (Peterborough, Ontario [etc.], 2004), 
Its best known advocate, Charlotte Wilson - not only an anarchist but a founding Fabian socialist and a leading figure of the pre-war suffrage movement - is often offered as the eccentric figure that best illustrates the anomalous and contradictory nature of the English anarchist movement.

Informed by cultural-historical perspectives, recent global histories of the three to four decades before World War I, however, suggest alternate ways to think about the movements we call socialism, anarchism, and feminism. ${ }^{2}$ These histories highlight the ways that new technologies in communication and transport produced complex confluences of people and ideas, creating a rich cultural brew that is not easily organized into conventional ideological categories. Individual radicals and their fluid organizations met and diverged under many different labels: anarchists, anti-imperialists, New Women, eugenicists, vegetarians, and, most broadly of all, socialists. Charlotte Wilson's friends, allies and political causes appear prominently in all of these new studies, suggesting that her peculiar eclecticism might be representative of important submerged cultural currents; accordingly, tracing her political biography offers a way both to illuminate these underlying currents and to open new perspectives. ${ }^{3}$

pp. 370-379. See also Peter Marshall, Demanding the Impossible: A History of Anarchism (London, I992), pp. 488-49I; David Goodway (ed.), For Anarchism: History, Theory, and Practice (London [etc.], 1989), p. I; Max Nettlau, A Short History of Anarchism, Heiner Becker (ed.) (London, 1996), p. 209. The Russian anarchist Peter Kropotkin, himself part of the international refugee community in England, may have been the first to describe English anarchism as eccentric. See Martin Miller, Kropotkin (Chicago, IL [etc.], I976), p. I69. For histories of English anarchism see Hermia Oliver, The International Anarchist Movement in Late Victorian London (London [etc.], 1983); John Quail, The Slow Burning Fuse: The Lost History of the British Anarchists (London [etc.], 1978). See also David Goodway, Anarchist Seeds Beneath the Snow: Left-Libertarian Thought and British Writers from William Morris to Colin Ward (Liverpool, 2006); Haia Shpayer-Makov, "Anarchism in British Public Opinion, I 880-1914," in Victorian Studies, 3 I (1988), pp. 487-5 I6.

2. Benedict Anderson, Under Three Flags: Anarchism and the Anti-Colonial Imagination (London [etc], 2005); Ilham Khuri-Makdisi, The Eastern Mediterranean and the Making of Global Radicalism, I860-1914 (Berkeley, CA [etc.], 2010); Leela Gandhi, Affective Communities: Anticolonial Thought, Fin-de-Siecle Radicalism, and the Politics of Friendship (Durham, NC [etc.], 2006); C.M. Bayly, The Birth of the Modern World, I780-I9I4 (Oxford [etc.], 2004); Jürgen Osterhammel and Niels P. Petersson, Globalization: A Short History (Princeton, NJ, 2005); Mary Louise Roberts, Disruptive Acts: The New Woman in Fin-de-Siècle France (Chicago, IL [etc.], 2002). See also Marilyn Lake and Henry Reynolds, Drawing the Global Colour Line: White Men's Countries and the International Challenge of Racial Equality (Cambridge [etc.], 2008), which tracks a number of the movements and individuals discussed below in its examination of fin-de-siècle white identity.

3. The following discussion is principally drawn from my unpublished Ph.D. thesis, "Charlotte Wilson: Anarchist, Fabian, and Feminist" (Stanford University, CA, I987). The English journalist, anarchist, and peace activist Nicolas Walter was the first to research Wilson's life and to document her role in late Victorian anarchism. See his entry in the Oxford Dictionary of National Biography (Oxford [etc.], 2004), and the introduction to his edited collection of Wilson essays: Charlotte Wilson, Anarchist Essays, Nicolas Walter (ed.) (London, 2000). 
The virtue of biography as a form of historical analysis is that it requires us to take seriously and consider anew actions and beliefs that do not fit with our current typology of political history. Biography presents us with the stubborn fact that Charlotte Wilson lived, and that under her own terms, as well as those who looked to her for leadership, Fabian socialism, anarchist revolution, and women's emancipation were complementary causes. While one lesson to be drawn from biography is a reminder that historical figures were no less susceptible than we are to internal contradiction and mixed motives, Wilson's story also reminds us of what we stand to lose when we impose coherence and typological precision on a historical moment that was neither coherent nor clearly defined for those who experienced it. The terms Wilson used to describe her beliefs were unsettled in late Victorian London, and the particular ideas she tried to express lost out in the contest over meaning and definition, especially in the fight over the political meaning of British socialism. William Morris, designer, poet and political ally of Charlotte Wilson, described the elusive nature of political ideas when, in A Dream of John Ball, he pondered,

How men fight and lose the battle, and the thing they fought for comes about in spite of the defeat, and when it comes turns out not to be what they meant, and other men have to fight for what they meant under another name. ${ }^{4}$

The following inquiry into Charlotte Wilson's understanding of political terms is an effort to recapture alternate meanings employed by those who battled over the definition of socialism in late Victorian Britain. Like the new global histories, I argue that there was a rich and complex mix of radical ideas circulating in this period; I ground my exploration of their meaning and cross-currents in the political career and alliances of one woman and show that here, too, we can uncover a new way of looking at this period that reveals alternate meanings of familiar political labels. ${ }^{5}$

Walter's thorough and painstaking efforts to locate Wilson in the historical record remind us of the archival challenges of biography, especially of the lives of women. Wilson's emotional life and interpersonal relations can only be inferred from her sporadic presence in the preserved correspondence of prominent men, especially George Bernard Shaw and Karl Pearson.

4. William Morris, A Dream of John Ball, in Three Works by William Morris, with an introduction by A.L. Morton (London, 1977), p. 53.

5. Like Ilham Khuri-Makdisi in her study of the late Victorian and pre-war global Left, I argue that radicalism in this period "was more often than not a package of (sometimes inchoate) ideas and practices that were not codified, standardized, or homogenized, and in which cleavages between socialism, anarchism, social democracy, Fabianism, and other ideologies did not always or necessarily apply"; Khuri-Makdisi, Eastern Mediterranean and the Making of Global Radicalism, p. 8. While Khuri-Makdisi explores this "package of ideas" by focusing on the press in three eastern Mediterranean cities, I find an instructive parallel to her findings in the intersection and re-conception of radical ideas in the small but influential group of late Victorian intellectuals and radicals to which Wilson belonged. 
As a member of the late Victorian radical community, Wilson used a variety of terms to describe her substantive values and political goals. I argue that her choice of "anarchist socialism" as the most comprehensive way to describe her political ideology opens a new lens on this period and allows us to see it differently in at least three interconnected ways.

First, Wilson's choice to identify herself as an "anarchist" suggests that fin-de-siècle anarchism is better analyzed not as a "movement" but rather, as Benedict Anderson terms it in his recent study, as a "gravitational field", pulling together momentarily a disparate collection of intellectuals and political refugees from all over the world, a transitory and constantly shifting network made possible by electricity and cheap transit in the early stage of contemporary globalization. Anderson's exercise in "political astronomy" focuses on the lives of the individuals who were drawn into this protean field, and in so doing uncovers an alternate radical discourse, an anti-authoritarian critique of late imperial capitalism that was obscured by the ascendance of socialist parties seeking power in the bourgeois state. ${ }^{6}$ Critical to the cosmopolitan conversation Anderson describes, though unexplored in his account, are the voices of women, some of them refugees, many of them middle-class intellectuals like Wilson, who from their varied perspectives were also drawn to this anarchist "force field". As a leading spokesperson and financier of late Victorian English anarchism, Charlotte Wilson managed a wide-ranging, politically diverse switchboard of global connections. If we are historically justified in applying this fluid, permeable concept of anarchism, Wilson no longer appears out of place; her position in this complex, short-lived constellation of activists appears illustrative and points to alternate and important political ideas.

Secondly, Wilson's anarchist career suggests that the internal inconsistencies of British anarchism are not exceptional, but rather are emblematic of a dualistic tension within all the competing schools of late Victorian radical thought. While articulated under a variety of names, British progressive thought was shaped by a basic morphology that embraced two fundamental but oppositional values: individual freedom and communal equality. Even as the actual practice of politics revealed the inherent tension between these two values, British radicals promised to deliver both, animated as they were by the utopian vision of modern democratic theory. The "inconsistencies" in Wilson's political biography reflect this fundamental paradox in a way that is useful for historians of political ideas. Seeking a new way to express the radical goal of individual freedom, she identified herself as an "anarchist". At the same time, she claimed that social equality is both a product of and a precondition for freedom, so she

6. Anderson, Under Three Flags, pp. I-3. Ilham Khuri-Makdisi also analyzes anarchism in this way in her account of global radical connections in the Arab Ottoman world. 
also called herself a "socialist", or "anarchist communist", or "individualist socialist". She was trying to construct a new "name" for the old "fight", as Morris put it in A Dream of John Ball, and, like other members of the late Victorian Left, she searched for a political vocabulary that would embrace both essential but oppositional elements of the utopian democratic formula.

The third line of argument proposed here is that the fin-de-siècle movement most in need of re-examination for traces of "lost" meanings is that vast galaxy of diverse political goals that we retrospectively call "firstwave feminism". The naming conundrum is most acute here, where the modern Western term "feminism" is imported to a time when neither the economic foundations for such feminism nor even the word itself existed. The complexity and cross-currents within this fin-de-siècle "gravitational field" were too diverse to go under a single term and were reflected in the open-ended phrase most often used to describe it: the "Woman Question". Historians of women's political history face a taxonomical trap at the outset, since women, like other disenfranchised groups, are caught in the paradox of speaking on behalf of an identity not of their own making, of necessarily having to frame their universal claims to freedom in terms of their particular exclusion as "women". ' Historians of feminism, therefore, face the double hurdle of using today's terms in search of past alternate meanings within a movement that was in its own time forced to use terms and identities that reflected exclusion and powerlessness.

Wilson never called herself a "feminist", but her entire political career attests to the "feminist" meaning at the core of what she called "socialism", or, for over twenty-five years, "anarchist socialism”. Her political ideal as a woman was wholly merged with the radical democratic tradition, yet she was frequently faced with the paradox of representing a presumed separate female interest. She and other socialist women, for example, were constantly forced to qualify the term "worker" in order to include themselves in this category. They had to be "women workers", a term that explicitly set them apart in the very attempt at inclusion. That Wilson chose "anarchist socialism" as the most inclusive term, and the one best able to express her political ideal, suggests that a feminist understanding of this ideology was an important current pulsing though the complex spectrum of belle époque radicalism.

\footnotetext{
7. The linguistic paradox reproduced in the writing of "feminist" history as something separate from the history of radical democracy is addressed by Denise Riley in "Am I That Name?": Feminism and the Category of "Women" in History (Minneapolis, MN, 1988). Joan Wallach Scott traces this discursive conundrum in modern French history in Only Paradoxes to Offer: French Feminists and the Rights of Man (Cambridge, MA, 1996). For the paradox of writing the history of India using names and identities constructed by imperial Britain, see Dipesh Chakrabarty, Provincializing Europe: Postcolonial Thought and Historical Difference (Princeton, NJ, 2000).
} 
This third argument suggested by Wilson's career adds an important, but largely absent element to the new literature on global radicalism. If, as I argue, Wilson's late Victorian radicalism was fundamentally a struggle for sexual emancipation waged under the name of anarchism, then the pre-war global women's movement that she and other anarchist and socialist women later joined needs to be reconsidered in this light. Just as Anderson's work challenges the historiography that sees pre-war labor movements as culminating in socialist political parties, and Khuri-Makdisi's work challenges the nationalist historiography that sees pre-war eastern Mediterranean radicalism as culminating in the modern state, the following analysis of Wilson's anarchism challenges the historiography that sees the pre-war women's movement as culminating in the franchise, and suggests instead that this movement was an important part of a global revolutionary moment. British suffragists, labor internationalists, Ottoman intellectuals, and other pre-war dissidents re-examined by the new global histories, were perhaps far more radical in their goals and more relevant to contemporary political concerns than has been acknowledged in traditional political history.

\section{CHARLOTTE WILSON AND THE MEANING OF SOCIALISM}

Charlotte Wilson ("Lettie" Martin until her marriage to Arthur Wilson in I 876) was born in I 854 in the village of Kemerton on the GloucestershireWorcestershire border, to a family affiliated for three generations back with the evangelical movement in the Anglican Church. Her great-grandfather used his considerable wealth as a silk manufacturer to purchase parish livings for his clergyman sons and sons-in-law, some of whom went on to publish, build churches, and become leaders in the evangelical movement. ${ }^{8}$

The weight of evangelical duty was no doubt present in Charlotte Wilson's youth as the only child of Clementina and Robert Martin, a member of the Royal College of Surgeons who also worked for his district's Poor Law service. Historians have long noted the continuities between British socialism and the discourse of Christian duty and deliverance. ${ }^{9}$

8. On the family's expansive mission and considerable influence see the Rev. George Lea, Memoir of the Rev. John Davies, M.A. (London, I859), and Crockford's Clerical Dictionary (London 1858 ). While Wilson may have broken her intellectual ties to the evangelical tradition by 1876 , she renewed her emotional links that year by marrying her cousin, Arthur Wilson, son of the Vicar of Islington, grandson of the Bishop of Calcutta and part of the same evangelical family dynasty.

9. See Barbara Taylor, Eve and the New Jerusalem: Socialism and Feminism in the Nineteenth Century (London, I983). Taylor suggests, as I do here for the late Victorian socialist revival, that the meaning of socialism was inextricable from a notion of women's liberation for members of the early socialist movement. See also Sheila Rowbotham and Jeffrey Weeks, Socialism and the 
Wilson fits this pattern, as her socialist writings are a palimpsest of evangelical moral accountancy, but with a marked rejection of institutional authority and discipline that may well reflect rebellion against the weight of a prominent family reputation. One of the few recollections she gave of her childhood suggests a critical awareness of the regime of Christian guilt, especially as it weighed on women: "I had myself a mother who, whilst in a sense she loved me intensely, yet always looked on me as an affliction sent against her will from on high, for which, as for other chastenings, she ought to feel grateful." ${ }^{10}$

Wilson was first exposed to the radical ideas that she would eventually label anarchist socialism as one of the original students at Newnham College, founded at Cambridge in I87 I as one of the earliest elite institutions of higher education for women in England. Located just outside the main college area in Cambridge, this bold experiment in female education recast the evangelical values of charity and improvement into secular and radical terms. In Wilson's own description, "Cambridge was the porch through which I entered the world."II The idea of women living apart from fathers or husbands to receive an education designed for men was one of the most provocative notions circulating in England in the I870s. ${ }^{12}$ The fin-de-siècle debate over which economic system would produce the healthiest "race", a constant topic of discussion that cut across all factions of the socialist movement, was already raging at Cambridge in the I870s, with respected scientists advising against intellectual

New Life: The Personal and Sexual Politics of Edward Carpenter and Havelock Ellis (London, 1977); G.M. Young, Portrait of an Age: Victorian England (London, 1977).

ı. Wilson to Pearson, 8 August I88, Karl Pearson Papers [hereafter, KPP], Watson Library, University College, London.

II. Wilson to Shaw, is July i889, AM 505 I2, fo. I6I, George Bernard Shaw Papers [hereafter, SP], British Library, London.

I2. The Principal of Newnham College, Anne Clough, insisted that higher education for women was a matter of general social improvement, not of "women's rights", and she instructed her students to steer clear of that phrase. In spite of Clough's efforts, outsiders saw these women as "revolutionaries"; See Blanche Athena Clough, A Memoir of Anne Jemima Clough (London, I 897), p. 195. The women themselves preferred to identify as soldiers for the "Cause", a placeholder called upon thirty years later to give a name to the women's suffrage movement; see Mary Paley Marshall, What I Remember (Cambridge, 1947), p. Io. Note that Wilson first met at Cambridge the future suffragist leader Millicent Garrett Fawcett, who was present there not as a student, but as the wife of the progressive don Henry Fawcett, and an active supporter, along with her husband, of the Newnham College project. As in the pre-war movement, the battle over women's education reflected real concerns about women wielding power, since Cambridge graduates were entitled to vote on a wide range of university affairs. The struggle from the I 870 s until women were admitted to university membership in 1948 can thus be seen as the academic version of the struggle for the national franchise; see Rita McWilliams Tullberg, "Women and Degrees at Cambridge University, I862-1897", in Martha Vicinus (ed.), A Widening Sphere: Changing Roles of Victorian Women (Bloomington, IN, 1977), p. I25. 


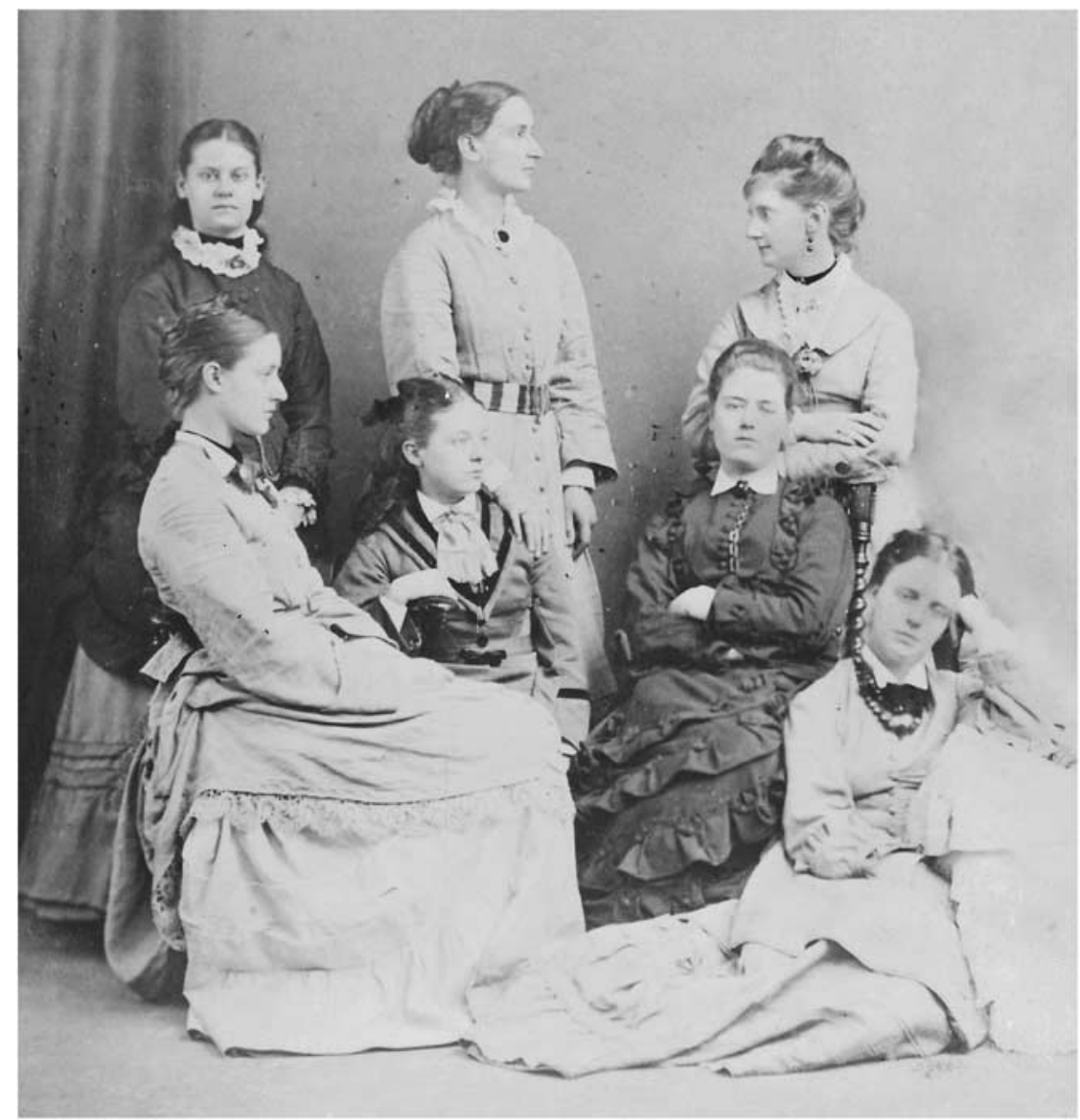

Figure I. "Cambridge was the porch through which I entered the world." Charlotte Martin (Wilson) stands at the far left and looks directly at the camera in this photograph of Newnham College students, taken in either I 873 or I 874 . Her lifelong friend and socialist comrade, Emma Brooke, is standing on the right.

Photograph reproduced with the permission of the Principal and Fellows, Newnham College Cambridge.

work for women and accusing women like Wilson of selfishly seeking their own education "at the price of a puny, enfeebled and sickly race". ${ }^{3}$

Like all the other women studying at that time, Wilson left Cambridge without a university degree, but she took with her a lifelong community of friends who would work with her in carrying the struggle against

I3. Dr. Henry Maudsley, "Sex in Mind and in Education", The Fortnightly Review (April I 874); see also Joan N. Burstyn, Victorian Education and the Ideal of Womanhood (London, I980), pp. $84-98$. 
established authority into the socialist movement. She also left Cambridge with a fluency in the language of positivist social science, an ability to engage in masculine discourse about economics and evolution that made hers one of the handful of female voices audible in the radical debates. Her anarchist writings drew upon the theories of Professor Henry Maine's Ancient Law to show that laws and governmental institutions impeded rather than accommodated the natural evolution of reason and social morality, a social science "fact" recognized by many of her radical colleagues, whether they identified themselves as anarchists or not. ${ }^{14}$ The critical role played by public opinion as a replacement for law in Wilson's anarchist theory found support in Professor J.R. Seeley's Ecce Homo, which described Christ as a revolutionary who defied Mosaic law in favor of a stateless "Universal Commonwealth". ${ }^{\text {Is }}$

The evolutionary history Wilson learned at Cambridge carried an implicit challenge to the Victorian family and to the legal subordination of women. The focus of Ancient Law was on the family and kinship as the basis of social organization. At any given stage of historical development, the family reflects the superstitions and failures of the culture at large. Laws restricting the development of women are just as harmful as any other artificial barriers to free evolution. While these claims were advanced as scientific knowledge, not as politics, they provided unquestioned assumptions from which a variety of socialist and anarchist claims about women and the family would be made.

Soon after they married, Charlotte and Arthur Wilson set up house in the stylish and slightly bohemian north London community of Hampstead. For Charlotte Wilson, the move to Hampstead must have seemed like a Cambridge homecoming, as two of her closest friends from Newnham, Emma Brooke and Henrietta Muller, were settled there, and the local culture was fully engaged in the discussions of economics and history that had structured her studies. ${ }^{16}$ In this community Wilson began her lifelong career

14. See, for example, "The Family as a Type of Society", The Anarchist, April i 886; "The Marriage Controversy", Freedom, October i 888. See also Emma Brooke, "Each Sex its Own Moralist", The New Review, December i 895. For a recent study of Henry Maine and his place in the "historical constellation" of new ideas of empire and liberal theory in late Victorian Britain, see Karuna Mantena, Alibis of Empire: Henry Maine and the Ends of Liberal Imperialism (Princeton, NJ, 2010), p. 8.

I 5. John Robert Seeley, Ecce Homo: A Survey of the Life and Work of Jesus Christ (London [etc.], I866), especially pp. I80-185, 317-32 I. See also Sheldom Rothblatt, The Revolution of the Dons: Cambridge and Society in Victorian England (New York, I968), p. I60.

16. Both Brooke and Muller continued to work in the women's cause, Brooke as a novelist, most notably as the author of $A$ Superfluous Woman (1894), and Muller as the publisher of The Women's Penny Paper, the first women's newspaper in London. Both women worked with Wilson and the Freedom Group on a number of occasions, though they called themselves socialists rather than anarchists. 
as an organizer, working with other young middle-class intellectuals to implement the social theories they had read, debated, and endorsed.

One of the numerous organizations Wilson formed or joined, starting in the late r 870 s, was the Hampstead branch of the London Society for the Extension of University Teaching, which she and her neighbor H.H. Asquith led as co-secretaries. Wilson and the future Liberal Prime Minister as co-officers in a cause offers an ironic picture, given their positions on opposite sides of the suffrage barricades thirty years later, but it illustrates the way in which a "movement" can have members with very different understandings of the movement's substantive meaning and goals.

While the university extension program was designed and promoted as a way to enlighten working-class men, the classes in all the London branches were attended primarily by middle-class women, many of whom went on to earn high marks and startled praise from their Oxbridge examiners. ${ }^{17}$ The Metropolitan Association for Befriending Young Servants, whose North London branch Wilson organized in I 880 , offers another example of cross-currents and mixed intentions within a single organization. The Metropolitan Association, a significant pillar in the massive edifice of British women's philanthropy, was structured as a Christian charitable organization and was organized primarily by the wives of evangelical clergy. Nonetheless, Wilson was publicly advocating secularism and anarchist revolution at the same time that she was volunteering and organizing in this organization, in which she remained active through at least $1885 .{ }^{18}$

She frequented the East End of London both to advocate anarchism and to work with Henrietta Barnett, wife of the pious founder of Toynbee Hall, in providing Christian assistance and instruction to impoverished girls. From her Hampstead base, Wilson also helped to organize an eclectic alliance in support of the Russian anti-tsarist cause, a movement idealized by a wide range of British progressives. With Edward Pease and Annie Besant, she organized the "Society of Friends of Russia" in the summer of i 885 . Wilson delivered lectures, published articles, and held gatherings in her home to support "nihilism", a cause she described as a successful combination of fierce Russian individualism with a perfect

I7. In expectation that women, rather than working men, might attend some of the day classes, a higher fee was charged for those sessions. But the evening lectures as well were delivered almost entirely to women. See London Society for the Extension of University Teaching, Report of the Council, I877-I884, Department of Extramural Studies Archive, University of London. See also the numerous reports in the Hampstead and Highgate Express, 1879-1880. I 8. See Metropolitan Association for Befriending Young Servants, Annual Reports, I877-I 886, British Library, London. Note that Millicent Garrett Fawcett and other supporters of women's higher education were also involved with the Metropolitan Association. See Helen Blackburn (ed.), A Handbook for Women Engaged in Social and Political Work (Bristol, I88 I), for a sense of the complex web of charitable and educational women's organizations in the early I88os. 
form of village communalism, the "mir", an ideal that embraced, as did all of her descriptions of the good society, both of the fundamental but oppositional elements of the democratic formula. ${ }^{19}$

The search for a cause that would offer both individual freedom and communal order dominated yet another of Wilson's small-group enterprises based in Hampstead in the I880s. Wilson organized "The Karl Marx Club" in I 884 as a study group for reading Capital. "Mrs. Wilson's economic tea parties", as Sidney Webb called them, have been described by historians of British socialism as "the seedbed of Fabian attitudes and policies", and certainly the principal figures of the early Fabian Society were all members, including Webb, George Bernard Shaw, Annie Besant, Sydney Olivier, Graham Wallas, and others. ${ }^{20}$ What is less often noted is that after tackling Marx, the group devoted a full year to the study of anarchism and changed its name to "The Proudhon Club", before finally adopting the more innocuous title of "The Hampstead Historic Society". The members included not just early Fabians, but French and Russian political refugees, literary and artistic figures like Olive Schreiner, William Morris, and Edith Nesbit, scientists of sex and eugenics Havelock Ellis and Karl Pearson, native working-class men like John Burns, prestigious academics like F.Y. Edgeworth and J.R. Seeley and, once again, Wilson's neighbor and friend H.H. Asquith.

Over the course of four years, this eclectic group sought to survey the best of what it called "socialist thought", a body of literature that for them included papers on "The Woman's Movement" by Percival Chubb (a member of the New Life Fellowship and commune), on "Humanitarianism" by Henry Salt (vegetarian, animal rights activist, and cultural guide to Mohandas Gandhi during his London years), and on a number of works that are significant here for their "anti-state" message, whether designated "anarchist" or not. ${ }^{2 \mathrm{I}}$

19. See Charlotte M. Wilson, "The Condition of the Russian Peasantry", Today (July and August I885). See also Wilson to Pearson, 4 November I885, KPP. Though short-lived, the Society of Friends of Russia established a basis of support among influential liberals that allowed its successor organization, the Society of Friends of Russian Freedom, to rally antitsarist sentiment on an international scale five years later. See John Slatter, "Stepniak and the Friends of Russia", Immigrants \& Minorities 2 (March 1983), pp. 33-49; Ron Grant, "The Society of Friends of Russian Freedom, I890-1917: A Case Study in Internationalism”, Scottish Labour History Journal, 3 (1970), pp. 3-24.

20. Webb to Shaw, 4 November I 884, AM 505553, fos 67-68, SP; Norman MacKenzie and Jeanne MacKenzie, The Fabians (New York, 1977), p. 64; A.M. McBriar, Fabian Socialism and English Politics: 1884-19I8 (Cambridge, 1962), p. 30.

21. Dr John Burns-Gibson's paper on the relation between anarchism and the Woman Question was so important, in Wilson's view, that it was delivered twice; Wilson to Pearson, 30 March I 886, KPP. See also Wilson to Sparling, 7 March I886, \#3258, Socialist League Archives [hereafter, SLA], International Institute for Social History, Amsterdam; and Brooke to Pearson, I4 March i886, KPP. 
The energetic Charlotte Wilson was a founding member of two more groups in the r 880 s, similarly diverse and similarly marked by the search for a social formula that would reconcile individual autonomy and social cohesion. Wilson was one of the organizers that led to the formation of the anarchist Freedom Group, discussed separately below, while she was simultaneously involved with a new socialist organization called the Fabian Society, whose original Executive Committee included Wilson as the only female member. Both groups, along with the other groups described above, included a roving band of middle-class intellectuals, artists, political refugees, and social scientists, none of them quite sure of the meaning of their particular ideological label. The Fabians, the Freedom Group, William Morris's Socialist League, and even the strongly Marxist Social Democratic Federation shared an overlapping pool of members and supporters, many of whom rejected party politics and most of whom dreamed of a stateless, post-revolutionary society.

The twentieth century legacy of Fabian state-dominated social engineering and non-revolutionary "permeation politics" has tended to obscure the ideas of the anti-state and revolutionary elements of the Society as it struggled to define itself in its early years; to refer again to Morris's metaphor, those who "lost the battle" in the fight over British socialism's meaning are hard to see in a historical narrative that equates Fabianism with the bureaucratic state. The artist Walter Crane recalled that when, already a member of the Socialist League, he joined the Fabian Society in 1885 , "the essential difference between anarchistic and socialistic ideas and aims was not then very well understood or generally recognized". ${ }^{22}$ While Crane considered himself to be a socialist, rather than an anarchist, he was described by contemporaries as the "anarchist aesthete" and felt sympathetic enough with Wilson's anarchist cause to contribute his artwork to Freedom throughout her period of editorship, as did the poets and fellow Fabians, Ernest Radford and Edith Nesbit.

Sydney Olivier, another founding Fabian, contributed regularly to Wilson's journal Freedom, offering some of the best defenses of anarchist socialism to appear there, though always under the signature of "a nonanarchist correspondent". ${ }^{23}$ Like Edward Pease, the first Secretary of the Fabian Society, Olivier preferred to call himself a "socialist individualist", but both men were careful to define their socialism as something beyond the mere pursuit of power in the parliamentary state. As Pease explained, to adopt a state-centered definition of socialism would mean that "a body of serious men and women are prepared to sacrifice their time and their money, and if need be, their lives, merely in order to obtain a great system

22. Walter Crane, An Artist's Reminiscences (London, 1907), p. 258.

23. See Freedom (July I 887 , October I 887 , November I 888). 
of bureaucracy and a host of public officials, and a mechanical routine of life devoid of all individual initiative". ${ }^{24}$

While George Bernard Shaw steadfastly refused to call himself an anarchist, he worked closely with his good friend Charlotte Wilson throughout her career as an anarchist and showed a lifelong distaste for the state, "an institution altogether repugnant to the principle of Freedom". Indeed, Shaw's first work ever published in America was an article he originally wrote at Wilson's request. Called "What's in a Name?", it was devoted to clarifying the terms used in the socialist movement. Of the two schools of socialist thought, "anarchist" and "collectivist", Shaw explained, the latter "would drive the money-changers from Westminster only to replace them with a central administration, committee of public safety, or what not", while the anarchists target the root cause: "We shall never get rid of slavery until we have got rid of authority." ${ }^{25}$ Shaw's own history of the Society conceded that there were as many anarchists as "collectivists" in the early years. ${ }^{26}$ Even in Shaw's Fabian tract meant to show the "Impossibilities of Anarchism", he painted an unappealing picture of the state socialist future, where we shall "still be living like hogs, except that each hog would get his fair share of grub", and he managed to ally himself with Kropotkin by describing him as "really an advocate of free Democracy", and not an "anarchist" at all. ${ }^{27}$

Another early Fabian, Edith Simcox, preferred the terms "liberalism" and "socialism" to express the twin ideals of individual freedom and collective unity, and she urged the Society to adopt the policy of "socialistic liberalism". ${ }^{28}$ Even Annie Besant, a consistent supporter of Fabian participation in parliamentary politics, shared with many other Fabians an inveterate distrust of laws and governmental institutions. Like most secularists, Besant

24. Edward Pease, "Ethics and Socialism", The Practical Socialist (January I 886); Pease's views were described by The Anarchist as "Anarchist ethics" (August I885). In a letter to Marjory Davidson, Sidney Webb equated anarchism with individualism and then agreed that Pease "possesses, as Mrs. Wilson acutely says, the Anarchist mind"; Norman MacKenzie (ed.), The Letters of Sidney and Beatrice Webb, 3 vols (Cambridge, 1978), I, p. I 2 I. Although he and his partner Beatrice Webb are the Fabians most closely identified with socialism as the bureaucratic welfare state, Sidney Webb was a close friend and collaborator with Wilson throughout their lives, and in the I880s he clearly defined anarchism as an important strand within socialist theory; see Sidney Webb, What Socialism Means (London, i 890).

25. Shaw's article was published in the first issue of The Anarchist (March I885), and then reprinted in Benjamin Tucker's American anarchist journal, Liberty. See correspondence between Shaw, Seymour, Tucker and Wilson in AM 50510 and 505 I I, SP.

26. George Bernard Shaw, The Fabian Society: Its Early History (London, I892), pp. 3-4.

27. Idem, The Impossibilities of Anarchism (London, I 893). This was originally published in Annie Besant's journal, Our Corner, in I888. Kropotkin himself noted in a letter to Shaw that "in politics we are not so very distant from each other"; 7 February I9I3, AM 50516, fos 298-299, SP.

28. Edith Simcox, The Practical Socialist (February i886). 
frequently expanded her attack on the church to include criticism of the state that supported it. She called herself a "state socialist", but proceeded to define her ideal state as an institution so democratic as to be synonymous with each of its individual citizens: "Whatever the State does is done by the people to the people, and is no infringement of individual liberty. State socialism thus is equal to perfect individual freedom." ${ }^{29}$

Whether posed as "socialism" and "individualism" leading to a "communist" ideal, or "collectivism" and "anarchism" comprising a "socialist" whole, the vision of the future shared by the Fabians was consistently a dualistic one, encompassing and reconciling the utopian conundrum of individual freedom within a social order. It is not surprising, therefore, that when the Society attempted in I 886 to state "What Socialism Is" in Fabian Tract \#4, the answer was two-fold, with Charlotte Wilson providing the anarchist definition and an extract from August Bebel's Women Under Socialism serving for the collectivist response. ${ }^{30}$ For Wilson, the anarchist meaning of socialism "lays no less stress than Collectivism upon the economic or materialistic aspect of social relations", but requires as its first step an education in free forms of interpersonal relations so as "to make apparent in their true force the real social bonds which already knit men together", a process incompatible with party politics. While the collectivist definition advocated participation in electoral politics with the goal of capturing control of the state, the next stage envisioned by Bebel differed very little from Wilson's future of federated communes. Bebel defined the socialist "state" to mean "the community organized administratively; for the State as we know it - an organization for the maintenance of monopoly - will abolish itself by the act of "expropriating the expropriators'". ${ }^{31}$

The collectivist/anarchist divide, therefore, was reduced to whether Wilson's moral evolution or Bebel's political seizure of the state was the proper path to the common socialist future. The importance of the former route was admitted even within the collectivist camp which, Bebel explained, was "divided into Revolutionists, who disdain all political action, and wait till evolution brings the moment for radical change; and Opportunists, who by political action aim at using the organized force of

29. Besant quoted in W.P. Ball, Mrs Besant's Socialism (London, I886), p. 4. Like Wilson and many other middle-class socialists, the language she used to describe her ideal was resonant with the terms of her lost Christian faith: "Perfect Socialism is consistent with, nay necessary for, perfect Individualism [...]. The three are one, just as the Trinity is one, or husband and wife are one; only Socialism is that one"; Our Corner (October I 885).

30. Friedrich Engels was originally asked by the Fabian Executive to draft the collectivist portion of the tract, but he declined; Executive Committee Minutes, 23 December I885, C 8/I3/I, Fabian Society Archives [hereafter, FSA], British Library of Political and Economic Science, London.

3 I. The Fabian Society, What Socialism Is (London, I886), p. 7, reprinted in Wilson, Anarchist Essays, pp. 45-53. 
the State as it is, to transform it into the State as it ought to be". Thus, the endless fission in the European ideal of socialism was still at work in German social democracy, no longer a contest between "collectivists" and "anarchists" (many of whom had taken refuge in London), but between "revolutionists" and "opportunists" within the collectivist party.

\section{ANARCHIST SOCIALISM AND THE "WOMAN QUESTION"}

It is significant that the book chosen to represent the collectivist definition of socialism had as its subject the "Woman Question" and its relation to socialism. The ideal of new forms of fellowship between men and women is as persistent a theme in late Victorian socialism as the ideal of a communal order that preserves individual freedom. Indeed, as intellectual traditions as well as political movements, socialism and what is now called "feminism" are inextricable. The democratic ideal from which socialism evolved posited the equality of husband and wife within the family as the basis for rejecting absolutism in political relations. As a new model of individualism that rejected all authority not based on consent, democratic theory established principles that could be applied to every form of domination, including sexual. Yet, elsewhere in this theory the patriarchal family is described as the only "natural" institution, as a pre-political sphere where the tension between self and society was erased through the merging of woman's individuality into that of her husband's. ${ }^{32}$

As the nineteenth-century heir to this radical tradition, socialism embraced both of these contradictory strands. "The degree of emancipation of women is the natural measure of general emancipation", wrote Charles Fourier at the dawn of European socialism. In socialist schemes that championed the oppressed, women held the honor of being the most oppressed of all, for in the family, according to Engels, the man "is the bourgeois and the wife represents the proletariat". ${ }^{33}$ Yet, elsewhere Engels described the "neutering" of the male worker by his wage-earning wife as the most grotesque of capitalism's many disastrous consequences. ${ }^{34}$ While Engels and many other state socialists disagreed with anarchists over the best means to achieve the mutually desired communist end, they shared with many anarchists a dream of the communist future in which women as mothers and men as providers would be free to return to their "natural" roles.

32. For the contradictions with regard to the family in classic democratic theory, see Carole Pateman, The Sexual Contract (Stanford, CA, I988), and Susan Okin, Women in Western Political Thought (Princeton, NJ, 1979).

33. Friedrich Engels, The Origin of the Family, Private Property, and the State (New York, 1942), pp. 65-66; Fourier is quoted in Taylor, Eve and the New Jerusalem, p. x.

34. Friedrich Engels, The Condition of the Working Class in England, (Stanford, CA, I968), pp. I6I-I62. 
While the word "socialism" seemed to count as many definitions as there were "socialist" organizations in late Victorian Britain, all these definitions and advocates agreed that socialism meant "freedom" for women, even while the picture of what that "freedom" looked like varied from socialist to socialist. Every organization that called itself socialist included in its constitution a demand for equal rights between men and women. The socialist journals proclaimed that the "Woman Question" "is part of the whole Social Question [...] that the emancipation of man and that of woman are equal necessities, that we cannot have the one without the other". ${ }^{35}$ If, like Charlotte Wilson, you took the "Woman Question" seriously, and saw it as the central issue within a historical movement for individual freedom and social justice, the single most inclusive term you could have used in the I 880 s to describe your commitment would likely have been the word "socialism".

From the outset, Wilson identified herself not simply as a socialist, but as an anarchist socialist. As one whose political ideas were formed in the company of women fighting against institutional exclusion in higher education, it is not surprising that the socialist Wilson would be drawn to the anti-state position in the debate over participation in electoral politics. The unifying thread that runs through the various campaigns led by middle-class women in Victorian Britain is a rejection of the masculine state and its disabling, immoral, and intrusive laws. The anti-state rhetoric found in anarchist journals was no more censorious than the libertarian language of women's rights literature, as these women proudly hailed their movement as the first truly international cause, composed of the women of the world who had political rights in no nation. ${ }^{36}$ For Wilson to adopt the state socialist strategy of electing representatives to Parliament would be to place the future of socialism in a governmental system that she and other women could not enter and that enforced their subordinate position through a myriad of laws. The collectivist picture of socialist MPs representing the interests of all looked suspiciously familiar to women. It was the same argument for virtual representation that had excluded the working man in I 832 and women at every occasion of franchise reform. Wilson had historical reasons to doubt the legitimacy of representative democracy and to object to the identification of socialism with that political form.

Wilson's position in the anarchist camp was also supported by the most recent advances in social science. In Freedom Wilson summarized the work of Lewis Henry Morgan who had shown that "sex relations have played as fundamental a part as economic relations in social evolution",

35. Commonweal (July i 885 ).

36. Muller's Women's Penny Paper was relentlessly anti-state, though Muller never identified herself as an anarchist. It reported on women's activities all over the world and explicitly identified international peace with the cause of women. 
a lesson that "Karl Marx and the historical school of economists in Germany", with their focus on "laws and governments, class struggles and foreign wars", had been slow to learn. ${ }^{37}$ The new field of anthropology and evolutionary culture had placed the subject of sexual reproduction at the center of intellectual life, and a broad range of critics questioned whether bourgeois matrimony was the best arrangement for producing a eugenically robust population. Wilson and large numbers of her socialist colleagues answered this question with an emphatic no, claiming that the law-bound system of monogamy was as destructive of reproductive health as was the ruinous capitalist system to which it was attached. As a socialist, she shared the widespread assumption that there was a prior period of matriarchy before the introduction of private property. But as an anarchist, Wilson highlighted the link between the end of this matriarchal communism and the introduction of law and government. The state came into being, under her reading of history, precisely to protect the capitalist's ownership of property and the husband's ownership of his wife.

Charlotte Wilson's advocacy of anarchism sounded most confident when she characterized the family of the anarchist future, a reproductive arrangement that would be both liberating for women and eugenically sound. She frequently pointed out that in the present system the most intelligent women were the least likely to reproduce, since to do so required them to enter into an institution that put them on a juridical par with children and lunatics. In "The Family as a Type of Society", first published in The Anarchist in I886 and republished later that year in Paris, Wilson surveyed ancient societies and the origins of the state and concluded that the authority of the husband plants the seed for "the spirit of dominion and the habit of domineering" in society at large. Born in the bourgeois family and then embedded in law, the dominating spirit prevents the natural development of the family into its next and final form: "A society of free equals, of friendly men and women, who know how to give and take, understand sharing and the community of work, rest, and enjoyment. [...] This autonomous commune of autonomous units, the springs of whose life are in reasonable good will, is Anarchism realized."

Wilson was not alone in placing a revolutionized model of interpersonal relations at the starting point for socialist revolution. Her image of the family of the future resembles other pictures that appeared across all branches of the socialist press. The Socialist League in particular, under Eleanor Marx's influence, persistently returned sexual emancipation to the center of revolutionary propaganda, and the League's Manifesto called for a society in which "kindly and human relations between the sexes" would

37. Charlotte Wilson, “The Marriage Controversy”, Freedom (October I 888). 
replace the existing "superstitions, moral and other". ${ }^{8}$ Edward Carpenter, chief supporter of the Socialist League in the north of England, embraced the anarchist understanding of socialism as the only way to uproot bourgeois hypocrisy, including the regime of compulsory heterosexuality. Like his friend and anarchist ally Charlotte Wilson, who frequently visited his vegetarian, simplified cottage in Sheffield, Carpenter imagined the deepest personal liberation as part of the revolution to come: "Lovers of all handicrafts and of labour in the open air, confessed passionate lovers of your own sex, Arise! Government and Laws and police then fall into their places - the earth gives her own Laws". 39

Wilson needed the support of male colleagues like Carpenter as she tried to frame the sexual revolution as an integral part of the universal emancipation movement, not the particular cause of women alone. Her reliance on the language of science to make the case for women's liberation helped place her in a neutral rather than partisan posture, but it also served to distance her from women less fluent in academic discourse. Edith Nesbit's first acquaintance with Wilson reflects the tension among middle-class women socialists as they vied for influence and prestige within the small, male-dominated, intellectual movement:

Mrs. Wilson [...] was a Girton girl and is clever and I am trying my very hardest not to dislike her. But it is difficult, as she is sometimes horribly rude and will never speak to a woman if she can get a man to talk to. I don't mean that she is a flirt - she isn't, but I suppose women are not clever enough for her to talk to. ${ }^{4}$

Wilson's need to identify with men in order to advance her own gendered meaning of anarchist socialism illustrates the paradoxical place of the "Woman Question" in the British socialist movement. While its banners and manifestos promised freedom for women, it was at the same time a movement in which the inherent intellectual inferiority of women was seriously argued, their physical inferiority being assumed without debate. Henry Seymour and H.M. Hyndman both used "womanish" as their

38. Commonweal (February 1885). The middle-class socialists imagined that the working classes were free from many of the sexual hypocrisies of bourgeois society. According to Bruce Glasier, "men and women of the working classes may more freely choose their companions and company"; J. Bruce Glasier, William Morris and the Early Days of the Socialist Movement (London, I92 I), p. 36. Similarly, the equal comradeship and "intimacy of social intercourse" among the young men and women of the Russian nihilist movement were an important part of that socialist myth; Sergei Stepniak, Underground Russia (London, I883), p. 8.

39. Edward Carpenter, Towards Democracy, quoted in Chushichi Tsuzuki, Edward Carpenter, I844-1929: Prophet of Human Fellowship (Cambridge, i980), p. 47.

40. E. Nesbit quoted in Doris Langley Moore, Edith Nesbit: A Biography (London, 1933), p. 72. Nesbit apparently confused Girton College, another of the pioneering experiments in women's education at Cambridge, with Newnham College, a common error. Nesbit, nonetheless, developed a close friendship with Wilson and often stayed at her home on the Heath. 
favorite term of abuse, while E. Belfort Bax believed that woman's most "prominent characteristic" was her "inability to follow out a logical argument". Bax particularly resented the pressure on male socialists to see women as comrades, to "read into their relations with their wives and other female associates an intellectual companionship which is not there" ${ }^{4 \mathrm{I}}$ As the leader of the Socialist League, William Morris knew that he had to show official support for what he called "the woman matter", yet in his journalism as well as his fiction, he pictured socialism as a promise that "women will neither get nor seek employment in work which men can do better" ${ }^{42}$ In private correspondence with his fellow League member Bruce Glasier, Morris stated, "of course we must claim absolute equality of condition between women and men, as between other groups, but it would be poor economy setting women to do men's work (as unluckily they do now) or vice versa". ${ }^{43}$

While the reasons for misogyny within the anarchist movement have been debated, its reputation for practicing sexist politics seems well settled. ${ }^{44}$ From the perspective of the late Victorian British experience, however, the anarchists seem no more misogynist than their state socialist counterparts. The misogynist (and anti-Semitic) Proudhon is usually the starting point for discussions of anarchist sexism, yet he had been dead for over twenty years by the time British anarchism organized, and while these intellectuals were interested in his economic ideas, they considered his views on women outdated since they were written before the breakthroughs in evolutionary science. Peter Kropotkin is the other anarchist theorist most often offered as representative of anarchist misogyny. But his scientific and cross-cultural interest in the history of marriage and the family, and his conviction that these institutions were fundamental in shaping economic and political life, made him more of a comrade with Wilson in the politics of the "Woman Question" than those socialists who saw the private sphere as irrelevant to politics. Kropotkin did at least consider domestic work to be a form of labor, and he elaborated schemes

4I. E. Belfort Bax, Reminiscences and Reflections of a Mid and Late Victorian (London, I9I8), pp. 197-198. For a thorough discussion of Bax's views and of the "Woman Question" within the Social Democratic Federation generally, see Karen Hunt, Equivocal Feminists: The Social Democratic Federation and the Woman Question, I884-I9I I (Cambridge, I996).

42. Commonweal (28 May i 887).

43. Norman Kelvin (ed.), The Collected Letters of William Morris (Princeton, NJ, 1987), II, p. 545 .

44. See Sharif Gemie, "Anarchism and Feminism: A Historical Survey", Women's History Review, 5 (1996), pp. 417-444; Richard D. Sonn, Anarchism (New York [etc], I992), pp. 55-59; John Hutton, "Camile Pissarro's Turpitudes Sociales and Late Nineteenth-Century Anarchist Anti-Feminism", History Workshop, 24 (1987), pp. 32-6r. For the prevalence of anti-feminism throughout the socialist movement, see Hubert van den Berg, "Pissarro and Anarchism", History Workshop, 32 (1991), pp. 226-228. 
for alleviating the drudgery of household chores, though like other socialists, men and women alike, he saw this as an exclusively female area of labor. ${ }^{45}$ To be sure, Kropotkin idealized the patriarchal home. But, again, this view was pervasive across all schools of socialist thought. The laboring man, his bulging biceps wielding a forge hammer in one arm while sheltering a woman and child in the other, is a prominent icon throughout all socialist literature.

The socialist William Morris and the anarchist Peter Kropotkin shared the same domestic dream depicted in Morris's News From Nowhere, where the hard physical labor is done by men, while women cook and serve and scatter "little twigs of lavender and other sweet-smelling herbs about the floor". In this post-revolutionary utopia, women "do what they can do best, and what they like best", which just happens to be housework: "Don't you know that it is a great pleasure to a clever woman to manage a house skillfully, and to do it so that all the house-mates about her look pleased and are grateful to her?”. No doubt, Charlotte Wilson felt the dissonance and crossed meanings within the movement when Morris, one of her closest allies and a figure of enormous respect among all socialists, has his protagonist ask:

You have studied the "emancipation of women" business of the nineteenth century; don't you remember that some of the "superior" women wanted to emancipate the more intelligent part of their sex from the bearing of children? The old man grew quite serious again. Said he: I do remember about that strange piece of folly, the result, like all other follies of the period, of the hideous class tyranny which then obtained $[\ldots] \cdot{ }^{46}$

Whatever frustrations and contradictions Wilson felt, she didn't let them interfere with her collaboration with men, though she may have shared them with Brooke, whose own frustration with Karl Pearson's understandings of socialism is evident in their correspondence. Karl Pearson called himself a socialist but at the same time took the position that "the subjection of women" was probably necessary as "the penalty to be paid for race-predominance". ${ }^{47}$ Brooke challenged Pearson, but ultimately agreed to disagree, concluding that "the misunderstanding lies where, between men and women, it always does lie - that is, in the use of the same words with different meanings". ${ }^{8}$

45. Peter Kropotkin, "Domestic Slavery," Freedom (July I 89I).

46. William Morris, News From Nowhere (1891), in Three Works by William Morris, pp. 196, $24 \mathrm{I}-243$.

47. Karl Pearson, The Ethic of Freethought and Other Addresses and Essays (London, 1901), p. 355 .

48. Brooke to Pearson, I4 March i 886, KPP. For an important study of the sexual politics of middle-class socialism, including an account of "The Men and Women's Club", to which Brooke and Pearson belonged, and which Wilson followed closely without apparently joining, 
For Charlotte Wilson, the anarchist cause was compatible with the emancipation of women in part because it wasn't focused on winning the vote of the working-class male. The anarchists, who rejected participation in parliamentary elections, could broaden their constituency to encompass immigrants, women, and other disenfranchised groups, while the state socialists increasingly structured their propaganda to appeal directly to the voting male worker and his organized trade unions. To champion sexual equality and the economic freedom of women was not the way to win applause from this audience. From its earliest years, the Trades Union Congress relied on the male worker's right to a "family wage" as its chief bargaining point, and it defined the aim of the labor movement as "to bring about a condition of things, where wives could be in their proper sphere at home, instead of being dragged into competition for livelihood against the great and strong men of the world". ${ }^{49}$ The state socialists, intent on mobilizing the electoral power of this group, supported tradeunion attacks on women in industry.

When the Weavers' Association went on strike against the employment of women in I 884, SDF Chairman H.M. Hyndman endorsed the efforts of the "workers" against the introduction of "female labour", noting that "it is the rule in all factory industry that women's and children's labour tends to displace that of men and thus to break up family life as well as to reduce wages". ${ }^{\circ}$ As an anarchist and as a woman, Wilson challenged Hyndman: "You apparently exclude women from the category of workers [...]. I submit that in the case in question, women are to be considered in every sense as much 'workers' as men." She further objected to his "classification of the labour of women and of children under one heading", and suggested that "instead of agitating for this indiscriminate dismissal”, the Weavers' Association should encourage the women to organize and demand equal pay. ${ }^{5 \mathrm{I}}$ Wilson reiterated these arguments in the debates over the Mines Regulation Bill of i 886 , which prohibited the employment of women at the pit brow. Pitching their propaganda toward the male miners, the state socialists supported the legislation as a way to protect men's wages and "prevent the deterioration of the race"..$^{2}$ Obviously aiming for a different group, Wilson endorsed female mine employment as a way to

see Judith Walkowitz, City of Dreadful Delight: Narratives of Sexual Danger in Late Victorian London (Chicago, IL, I992).

49. Henry Broadhurst quoted in Jane Lewis, “The Working Class Wife and Mother and State Intervention, 1870-1918”, in idem (ed.), Labour and Love: Women's Experience of Home and Family, I850-1940 (Oxford, 1986), pp. 99-1 20, 103.

50. H.M. Hyndman, "Women’s Labour in Factories", Justice (I March I 884).

5. C.M. Wilson, "To the Editor of Justice”, Justice (8 March I 884).

52. H.M. Hyndman in The Practical Socialist (January 1887 ). 
free the working woman and to deprive her husband of his "dependent domestic serf":

What claim have any class or section of the community to forcibly decide for another what is or is not a "suitable" occupation? Have our Radical fellowworkers found the legislation of capital for labour such an unmixed blessing that they set about the analogous business of the legislation of men for women? ${ }^{53}$

Wilson's anarchist attack on restrictive laws for women and her celebration of women's industrial labor were launched from her own middleclass perspective, which necessarily limited her ability to speak for the women actually working in the mines and as "serfs" for their husbands; the women she claimed to speak for might well have defined freedom as enough material security not to have to work. Nonetheless, her rejection of party politics as the path to the socialist future may have had a resonance that cut across class lines, as it certainly sounded a chord with a number of women in the movement, whether they called themselves anarchist or not. As Wilson put it, "the man who wins" in representative politics "is he with the loudest voice". The Fabian Caroline Haddon urged socialists to steer clear of politics and legislation "which is only made for rogues, and serves but to inform them how far they may lie and cheat with impunity and where they must draw the line to avoid unpleasant consequences". ${ }^{54}$ Edith Ellis agreed, arguing that "mere external reform, as advocated by the Marxian socialist, may still leave the individual as egoistic and narrow as before, and as much a danger to the general well-being of the community".s5 Legislated socialism and the permeation of existing institutions threatened to leave women just where the liberal revolutions had left them, excluded from politics and subordinated at home. ${ }^{56}$

Charlotte Wilson urged her fellow socialists to see that only anarchism could express socialism's meaning for women: "Anarchist Communism means, first of all, absolute freedom for every human being of either sex." ${ }^{\text {" }}$ Evolutionary history had taught her that state authority and submission to

53. C.M. Wilson, "Women's Labour”, Freedom (July I 887).

54. Caroline Haddon, Where Does Your Interest Come From? A Word to Lady Investors (London, I886), pp. 6-7.

55. Edith Ellis (Mrs. Havelock Ellis), Attainment (London, 1909) p. I59.

56. Again, this same conversation was going on under different terms within the German socialist movement. Rosa Luxemburg and Clara Zetkin fought the "opportunists" like Edward Bernstein who argued that socialism would evolve gradually through legislated reform. Rosalind Coward concludes that Zetkin's and Luxemburg's "philosophy on the transformation of the position of women was closely bound up with a classical Marxist theory of the total overthrow of capitalist social relations. Thus the defeat of that version of Marxism was a defeat of the woman question in social democratic politics"; Rosalind Coward, Patriarchal Precedents: Sexuality and Social Relations (London, 1983), p. I77.

57. C.M. Wilson, "What Anarchist-Communism Means", Freedom (August r 889). 
law is forever linked to the oppression of women. Wilson's dream of individual emancipation could only be realized with a total revolution in morals and institutions. "It is possible to conceive a tolerably intelligent man advocating palliative measures and gradual reform", she explained to the readers of Freedom, "but a woman who is not a Revolutionist is a fool". ${ }^{8}$

\section{ANARCHIST ACTIVIST}

As a political theory premised on the rejection of institutional authority, anarchism was immediately and always faced with a conundrum: how to organize and implement a revolutionary program without condoning the coercion and hierarchy your program rejects. The same theoretical purity that prevented anarchists from participating in bourgeois politics made them insist that their internal organization should also embody the principles of the future order: no officers, no chairmen, no rules or compulsory dues.

The anarchist press, by default, was the only structured and enduring organization, and propaganda rather than collective action was the principal form of politics. As co-editor with Henry Seymour of the Anarchist, and then as publisher and editor of Freedom, Charlotte Wilson's journalistic work and financial backing created the principal tangible evidence of anarchist politics in London. While some revenue came in from subscriptions and sales, the cost of paper, ink, postage, and the salaries of the few paid employees was carried primarily by Wilson. ${ }^{59}$ Not surprising given the interconnected and amiable progressive scene of the i 880 , the Freedom Group shared space and printing plant with other secularist and socialist groups until I 889, when Wilson and James Blackwell, the former manager of Justice, purchased the Group's own type and printing plant. The anti-authoritarian culture of anarchism, along with the greater number of immigrant and casually employed members, may have imposed more burdens on Wilson than other middle-class socialist editors. At Freedom Lectures, in fundraising drives, and in every issue of the paper, Wilson spoke of the high cost of propaganda and urged her readers to pay their share.

Anarchist politics was expensive for Wilson in time as well as money. She was the indispensable member of the Freedom Group, as is shown by the lengthy and detailed instructions she left when illness prevented her from coming to the office. ${ }^{60}$ She not only published a journal, she coordinated

\section{Idem, Freedom (October I 888).}

59. Note that Justice and Commonweal, although official organs of the Social Democratic Federation and the Socialist League, were likewise financed privately by their respective editors, H.M. Hyndman and William Morris.

60. See letter from Wilson, i I October i 888, \#3260, SLA. Though Wilson was too ill to come in, she prepared the labels and wrappers for that month's Freedom at home and sent them to the 
an international network as anarchists and their correspondence, literature, and journals passed through the Freedom office from all over the world. Correspondence and accounts from Japan, Algeria, Australia, South Africa, as well as from Europe and the Americas, suggest that anarchist journals like Freedom provided the principal means of structure and continuity on the international as well as the local level. In this polyglot web of revolutionary politics, Freedom served as the English-language clearing house for anarchist news, theory, and organization. Articles from Freedom were translated in the foreign left-wing press, and foreign-language copy from all over the world came into the London office of Freedom, to be translated and published in English. In this early stage of modern mass communications, the articles and lengthy correspondence columns of journals like Freedom were the media through which a global conversation could take place among an increasingly mobile and cosmopolitan radical network.

Significantly, women within this network were the ones often doing the actual work of translation. Wilson translated a number of Kropotkin's articles from French to English, as well as the works of Elisée Reclus, the anarchist philosopher and geographer, and of his anthropologist brother Elie, for both political journalism and for scholarly publication. Nannie F. Dryhurst, Wilson's closest associate in the hard work of anarchist publishing, also translated extensively, as did Agnes Henry, who was also both a Fabian and an anarchist. Wilson's efforts to find jobs for unemployed Russian exiles came back to her in the form of willing translators for the cause. Wilson brokered Russian lessons from the nihilist exile Sergei Stepniak for her friend Ethel Voynich. Soon Voynich was translating into and out of Russian, including Stepniak's Nibilism As It Is, and working alongside Wilson and others translating the mass of revolutionary literature that poured in and out of late Victorian London. ${ }^{61}$ They were assisted in this job by Wilson's fellow Newnham graduate and Hampstead neighbor, Constance Garnett and her sister Olive (also taught by Stepniak). Women served as interpreters at socialist and anarchist conferences and, on at least a few occasions, smuggled radical texts across borders, as their gender and middle-class status allowed them to pass without raising official suspicion. Whether interpreting, translating, bundling for post, or smuggling text, these women functioned as indispensable conduits through which a global, anti-state discourse was conducted.

office by messenger. At the end of the detailed mailing instructions, Wilson added that she would pay her comrades for the extra work her absence had caused. See also Wilson to Pearson, 26 May I887, 25 May i 892, KPP.

6I. Voynich met and married a Lithuanian refugee, learned Ukranian, and went on to write The Gadfly, a fictionalization of this international revolutionary culture that would itself be later translated into Russian and Chinese as it gained huge popularity in the twentieth-century communist regimes. The book, whose female protagonist "Gemma" was based on Charlotte Wilson, was also made into an opera and a film, with a score by Dmitri Shostakovich. 
Wilson's victory in enlisting Peter Kropotkin to her own cause (Morris and Hyndman both vied with Wilson for Kropotkin's alliance), is further evidence of the parallel and intersecting world of women progressives in this international milieu. Wilson traveled to France in I 884 to meet Sophie Kropotkin, like Wilson a pioneer in women's higher education. She was part of that international migration of women to Switzerland whose universities were unique in offering women advanced degrees in science and medicine. In bringing both Kropotkins to London two years later, Wilson was able to link the women's struggle for education with one of the most prestigious continental figures in anarchist politics, a natural merger under her own understanding of socialism's meaning. In London, Wilson put Kropotkin to work in the Freedom Group and brokered a teaching and speaking career for Sophie. ${ }^{62}$

Another legendary figure in the international radical culture whose alliance Wilson sought was the anarchist Communard, Louise Michel. Here again one finds a heterogeneous confluence of activists as Michel drew crowds of state socialists, secularists, and philanthropists, as well as anarchists. While the famous "Vierge Rouge" was sought as a soap-box draw by all of radical London, Michel remained largely aloof from organized anarchism in London and sought instead to maintain her ties with continental groups, including L'Union Internationale des Femmes, a French women's journal that considered all women part of the movement, even those who worked for government reforms. ${ }^{63}$ Just as the anarchist women's journals included non-anarchist women within their constituency, non-anarchist women journalists like Henrietta Muller reported favorably on the activities of anarchist women. ${ }^{64}$

The influence of a gendered understanding of anarchism is suggested by the support British anarchists gave for alternative schools and for theories of anarchist education. One of the few examples of practical anarchist politics, the short-lived "International School" in Fitzroy Square taught languages, music, and science under a method designed to "fit children for freedom". It enrolled over eighty children of all nationalities, with Louise Michel as headmistress and Henry, Dryhurst, and other members of the Freedom Group enlisted to teach. ${ }^{65}$ In support of Kropotkin's theory of mutual aid, women anarchists offered their own experiences with children as evidence of a natural capacity for voluntary cooperation. Not only were children drawn

62. Wilson also found paid teaching and translation positions for Fanny Stepniak.

63. See L'Union Internationale des Femmes (January i 889).

64. See for example Women's Penny Paper (8 March I 890), for a favorable review of Michel's anarchist theater production.

65. See Freedom (December I890, March i89i, September i89i, February I892). See also Crane, An Artist's Reminiscences, pp. 258-259, where the frontispiece he designed for the prospectus of the school is reproduced; Henry Nevinson, Changes and Chances (London, 1923), p. 3. 
to socially useful activities, they had a thirst for knowledge that compulsory education tended to destroy rather than promote. Wilson and Henry especially targeted the poor quality of education administered in the board schools, and claimed that one could track the decline of cooperation and intellectual curiosity in step with the rise of institutional authority and coercion children experienced upon entering these schools. ${ }^{66}$

Wilson's attack on state sponsored education is a useful reminder that the confluence of activists for women's equality was no more doctrinally coherent than was the anarchist network. While Helen Taylor was Wilson's socialist colleague in women's emancipation, Taylor was also a member of the London School Board, a collaboration with governmental authority that Wilson would not tolerate. Similarly, Louise Michel's admiration for Britain, including its laws and municipal police, points to divergent understandings of the "state" within the anarchist movement. ${ }^{67}$ Wilson must have found it hard to work up revolutionary fervor against her own state when her emigré audience so clearly admired the liberal traditions and political latitude of Britain. French anarchist Charles Malato warned newcomers that the food was terrible but that British laws and civil liberties were exemplary, making the country the freest in the world and a "refuge par non" ${ }^{68}$ Even more discordant perhaps was the willingness of some anarchists to call the police or file lawsuits to resolve disputes. ${ }^{69}$ Such apparent inconsistencies, both within the women's rights and the anarchist alliances, were always capable of theoretical resolution, as they were in the Fabian debates, by returning to a shared definition of the "state" as a community harmonious with individual freedom. While some activists pictured this ideal as the Russian mir, others as the British liberal constitution, and others as a school board run by women, the image of a community compatible with individual freedom was always available to unite this heterogeneous community.

While Wilson and her emigré colleagues might have differed in their views of the British political order, they did agree that revolutionary

66. See the following articles by Charlotte Wilson: "Education by Force", Freedom (November I886); "Some Facts About Compulsory Education", Freedom (January i 888); "Work", Freedom (July i888), reprinted in Wilson, Anarchist Essays, pp. 60-65; Freedom, (December I888, January I89I); “Anarchism IV”, Justice (December I884). Wilson frequently discussed her child-based theories of mutual aid in her correspondence. See Wilson to Pearson, 22 November I886, 30 November i886, KPP; Wilson to Shaw, io December I884, fos 310-3 I4, AM 505 10, SP. See also Agnes Henry "Education", Freedom (September-November 1892); and Freedom (January i 888, March i891, September i 89i and February i 892).

67. To Michel, England was "le pays de la liberté par excellence". She was especially impressed by the good manners of the police and the fairness of the criminal justice system; Louise Michel, Souvenirs et Aventures de ma vie (Paris, 1983), pp. 173-179.

68. Charles Malato, Les Joyeusétés de l'Exil (Paris, i 897), pp. I-23, 90.

69. See The Anarchist (January I889); Freedom (December I 890 and January I 891). 
propaganda rather than electoral politics was the proper form of anarchist activism. More so than state socialists, therefore, the anarchists depended upon a symbolic politics, a program that used ritual and spectacle in place of party programs and directives. The celebration of revolutionary history, for example, was the bread and butter of anarchist politics. Such spectacles involved a lot of labor, much of which fell to the women, such as making and installing the bunting and the banners, printing and distributing the song sheets and texts, arranging for the clean-up of venues, etc. In British anarchist circles, however, women also mounted the podium, as Wilson, Michel, Lucy Parsons (the wife of one of the Haymarket martyrs), and Ida B. Wells (the American anti-lynching activist), made villains of the state and heroes of the workers, workers described as women, sharecroppers, immigrants. ${ }^{70}$ Every January through March, Wilson was consumed with preparation for the annual commemoration of the Paris Commune, a potent symbol for the revolutionary Left and one that the anarchists worked hard to claim as their own. It was a republican state that ended this model of communist society and killed thousands of its own citizens, the anarchists reminded the large crowds gathered at Hyde Park every i 8th of March. Speaking to I, 500 radical celebrants at the i 888 commemoration, Charlotte Wilson devoted her entire speech to "the heroic daring" of the "women of Montmartre", and placed women's anarchist politics as central to the meaning of this revolutionary holiday:

The working women of Montmartre waited for no centralized organization, no word of command, but marched up the open streets against the leveled muskets of the soldiers. [...] When the fight was over, they bestowed equal energy upon the reorganization of social life. They formed committees to inquire into the wants of every family and to organize labour for women. [...]. Lastly, during the hot days, when the fight was raging in the streets, the women were seen everywhere. $^{71}$

70. Note that both Parsons and Wells were African Americans, perhaps the only non-whites at the time sharing a public podium with British socialists. While the converging and conflicting ideas about race in the socialist and suffragist movements are beyond the scope of this article, Wilson's ties to these women offer another possible window into this issue, especially in the context of Reclus's theories of the reproductive benefits of "racial fusion". See Elisée Reclus, "East and West", Contemporary Review, 66 (October I894), pp. 475-487; Fred Charles to the Socialist League, I4 November I888, \#2786, SLA, describing the "splendid success" of Mrs. Parsons's tour; Max Nettlau Archive [hereafter, MNA], Dossier: England, II.2; Freedom (June I 894), for a report on Ida B. Wells's speaking tour "to rouse public opinion against the barbarous exhibitions of race hatred which have lately taken place in the South States of America", where the laws that should be protecting the Negroes were "worse than useless". 7I. C.M. Wilson, "The Women of the Commune”, Freedom (April I 888). See also the reports of Wilson's speech in Commonweal (24 March I 888), and Justice (24 March I 888): “Mrs. C.M. Wilson said that $[\ldots]$ the effect of that revolt was not so much to be noted at the Hotel de Ville as in the homes and in the daily lives of the workers. It was in that direction that they must look for the real meaning of that great uprising." 
Wilson made an anarchist parable out of socialism's favorite story and placed the lesson in the freedom and bravery of women. She also linked women with the cause of revolution in her propaganda for women's right to work. The same Trade Union Congress that voted to exclude women workers also passed anti-immigration resolutions. In agitating against this policy and the state socialist parties that supported it, Wilson again placed women's freedom at the center of the debate.

The original idea of persecuting and coercing foreigners, imported by employers to undersell home labour, is giving way to the far wiser and more effectual remedy of combining with the working men of all nationalities against the common foe. The habit in each country of conceiving of the dwellers in all others as inferior sorts of animals is fast disappearing. I would suggest that the feeling shown by some men's Unions towards women-workers is a prejudice of the same nature, and equally doomed to fall before enlightened self-interest and the advancing sense of the solidity of mankind..$^{72}$

The anarchists' necessary reliance on texts and symbols corresponded with the very moment in the late nineteenth century when such messages began to be transmitted globally and in new, persuasive media. Nothing illustrates this intersection between revolutionary tactics and global discourse better than the socialist response to the trial and execution of immigrant anarchists for the I 886 incident at Chicago's Haymarket Square. A wide spectrum of European public opinion agreed that the men were wrongly condemned. The Freedom Group, the Socialist League, and other anti-state socialist groups took advantage of this view and made political hay out of the international incident. Using same-day information relayed telegraphically, and selling cheap reproductions of the defendants' words and photographs, they virtually transported an entranced public into the Chicago courtroom. Wilson and her colleagues, through public rallies, fundraisers, and international petition drives, kept Europe's attention focused on the Illinois Supreme Court as it considered and then rejected the men's appeal. On 6 November I 887, at 49 separate meetings convened in London alone, over 16,000 socialists and other radicals gathered to condemn the imminent "judicial murder" and to engage in virtual politics by sending collective telegrams urging the Illinois Governor to halt the executions. ${ }^{73}$

72. Wilson, "To the Editor of Justice", Justice (8 March i 884).

73. See the reports throughout I 887 in Freedom, Justice, Commonweal, Our Corner, and other socialist periodicals, especially "The Chicago Prisoners", Freedom (September i887); C.M. Wilson, "The Condemned Anarchists", Commonweal (I 2 November I 887); and "The Tragedy of Chicago," Freedom (December I 887). The additional costs of the Haymarket meetings and petitions were often picked up by Wilson and Morris. See Morris to Baker, 28 October i 887, \#2277, SLA; telegram from Sheffield Socialists to Mrs Wilson, I4 October I887, \#I0I8, SLA. For a recent study of Haymarket see James Green, Death in the Haymarket: A Story of 
Haymarket gave Wilson a ready example for years to come of the coordinated, inextricable force of law and capital. Freedom tied the actions of the state in Chicago to its even more violent actions in the colonial world. The late Victorian anarchist press is one of the best archives for tracking imperial history as it regularly reported on coercion by the state all over the globe, from India to the Sudan, Puerto Rico to Dahomey, Algeria to Tahiti. The formal separation between the metropolitan state and commerce dissolves in the colonies where they act in concert openly, the anarchists pointed out, a collusion masked in the metropolis through representative institutions and political parties. Wilson's close friendship with the South African writer Olive Schreiner provided her with ready text on "land robbery in South Africa", as Freedom chronicled and condemned state action in the Matabele War and disclosed its system for paying mercenaries with seized land and cattle. ${ }^{74}$

Freedom tracked state action from the imperial battlefield back to the domestic factories and mines on which it depended. Explosions at the Waltham Abbey Royal Powder Works in December I893 and several accidents in Welsh coal mines in I 894 were cited by Freedom as examples of "lawful" atrocities, along with the everyday violence of industrial disease and infant malnutrition. ${ }^{75}$ The anarchists, who themselves relied upon electronic transmission to convey their global message, were particularly attuned to the coercive power of this new technology when wielded by the state. Freedom informed its readers that it was the poor who usually suffer capital punishment, and disclosed the "inhuman experiments on human beings" taking place at Sing Sing prison in New York where the first executions by electricity were underway. ${ }^{76}$

Just as international anarchist politics were necessarily symbolic and spontaneous, they were increasingly reactive and defensive, as the consolidating British state grew more able to isolate, contain, and demonize the anarchist branch of the socialist movement. The state socialists' willingness to participate in parliamentary politics had gone a long way towards dissociating the term socialism from violent revolutionary action. The open endorsement of forceful revolution by some anarchists, along with the rejection of parliamentary methods by all anarchists, kept anarchism securely tied in the popular imagination with notions of dynamite, assassination, and violent revolt. By 1894 , the Fabians and other socialist groups were no longer willing to collaborate with the

Chicago, the First Labor Movement and the Bombing that Divided Gilded Age America (New York, 2006).

74. Freedom (January/February I 894); MNA, Dossier: England, "Freedom”, II. 2.

75. See Freedom (January/February I 894 and August I 894); "Revolution or War", Freedom (October I 89I).

76. MNA, Dossier: England, "Freedom”, II. 2 
Freedom Group, and Wilson found it increasingly difficult to find venues willing to rent to anarchists.

One of Wilson's most widely read anarchist essays was written in response to this association of anarchism with violence. "Anarchism and Outrage", first appearing in Freedom in December 1893 and then published as a pamphlet, circulated widely in the radical community and to a moderate extent among the general public, which was eager to read the views of a native "dynamitard" ${ }^{77}$ The essay is essentially a defense of a fundamental democratic value, the freedom of political speech. Wilson outlines the principles of anarchist socialism, endorsing once again the values of individual freedom and communal association, but with the accent on the individual: "The object of associating is to increase the opportunities of the individual." She then asserts the importance of free expression in maintaining this balance and distinguishes symbolic, property-focused "propaganda by the deed" from indiscriminate physical violence. But she closes in an apologetic mode, admitting that violence is to be expected from people "driven by desperate circumstances into this terrible form of revolt". Still speaking in the terms of her evangelical youth, Wilson urges absolution for anarchist sins: "The guilt of those homicides lies upon every man and woman who, intentionally or by cold indifference, helps to keep up social conditions that drive human beings to despair [...]. Let him who is without sin in society cast the first stone.”

\section{SUFFRAGIST CRITIC OF THE “MASCULINE STATE”}

Alfred Marsh took over as editor of Freedom in I 895. While Charlotte Wilson had many reasons to leave anarchist politics, the duties of a daughter were the cause of her departure, as she tended to her dying father and brought her mother to live with her in Hampstead. Wilson never renounced her anarchist beliefs, and she continued to provide occasional though diminishing financial assistance to Freedom. She also continued for the next six years to work from her home submitting periodic theoretical pieces, providing translations, and helping with the processing of foreign subscriptions. Her public participation in anarchist politics, however, essentially ceased.

Just as the I 880 s saw a proliferation of diverse but overlapping organizations, all devoted to a mutable notion called "socialism", the pre-war period was characterized by an even greater explosion of organizational

77. Anarchism and Outrage was translated into Dutch and German, quoted approvingly by Emma Goldman, and was still one of Freedom's better selling pamphlets in the pre-war years. In his study of anarchist political theory, David Miller devotes a full page to the discussion of Wilson's pamphlet as characteristic of the views "among the luminaries of anarchism"; David Miller, Anarchism (London, 1984), pp. I I9-I20. It is reprinted in Wilson, Anarchist Essays, pp. $73-80$. 
activity, multifarious in nature and integrated by devotion to an idea often termed the "Cause". While the specific understanding of the "Cause" was described in widely varying ways, by 1906 this capacious placeholder was understood at the minimum to imply support for women's suffrage. With her own, inevitably idiosyncratic understanding of its purpose, the anarchist socialist Charlotte Wilson joined the fight for the vote and soon rose to a position of leadership in the worldwide uprising of women that shook the halls of state in the first decades of the twentieth century. She no longer described herself as an "anarchist", a term that the state and the media had effectively equated with "terrorism" by the early igoos. But Wilson's second stage of intense political activism was in service to a movement substantively compatible with her own earlier rendering of the meaning of anarchism, a movement that for Wilson had always been synonymous with sexual equality, one that she had worked throughout the i 880 os to define as "absolute freedom for every human being of either sex" $7^{8}$

In I906, fifty-two years old and no longer caring for her mother, who died in 1903, Wilson left Hampstead, moved into a flat in central London, and began another ten years of intense political activity. ${ }^{79}$ She joined the Independent Labour Party, the Women's Industrial Council, the Women's Freedom League, and the Women's Local Government Society, which led to her election as a school manager, a post that gave her authority to appoint teachers and to report on the quality of public education. In I908, having renewed her ties to the Fabian Society, Wilson convened a group of women in her home and launched the Fabian Women's Group, to fight for women's suffrage, to provide historical and sociological literature in support of this movement, and, in Wilson's words, "to define the intimate relation between the two most vital movements of our time, Socialism and Women's Emancipation". $8 \circ$

As the spokesperson for women in the by now very influential Fabian Society, Wilson was in the spotlight again. She attended international conferences, used the Fabian press to publish histories of women, and joined suffragist delegations to the government, now led by her old friend Asquith. As she had done as an anarchist, the suffragist Wilson continued to keep an eye on the state and to oppose new, coercive legislation, especially protective legislation limiting the economic choices of women. The Fabian Women's Group led the charge against Lloyd George's National Insurance Bill, finding its inadequate benefits discriminatory against married women, and the package as a whole a form of "socialism for men". "In every case where the Bill touches women”, Wilson argued,

78. See above the section "Anarchist Socialism and the 'Woman Question"”.

79. The Wilsons also bought a country home in Oxfordshire. Arthur Wilson appears to have spent most of his time there from 1906 until his death in 1932.

80. The Fabian Women's Group, “To the Members of the Society”, 1908, FSA. 
it incorporates the assumption of a "family wage" and, "bears obvious evidence of being concocted by men for a voteless and subject feminine population.[...]. Socialists must recognize that women's economic revolt is not merely against the enslaving economic control of the capitalist, but against the enslaving economic control of the husband." ${ }^{\text {I }}$

Wilson's activism in the pre-war women's movement is beyond the scope of this article. I suggest, however, that here too her story might serve as a lens for revealing hidden definitions, for recovering meanings that do not conform to the standard historiography of the pre-war British suffrage movement. ${ }^{82}$ While an important strain in the movement cast the "Cause" in largely conservative terms, as a way to fortify the state as well as the empire, Wilson's biography reminds us that the dual values at the heart of the democratic tradition tend to generate oppositional meanings, so that we should expect contradictory understandings within the same political movements. As Wilson's experience in the I 880 s showed, by a process of redefinition, the commune, the state, and even the empire can each be imagined as a moral fusion of free individuals. Perhaps the prewar women's movement, like the earlier socialist revival, can be fruitfully reconsidered by highlighting these contradictions and by focusing on the varying entwined meanings behind the dominant labels.

Such an approach would lead us to ask new questions about the discourse of suffragism, especially its attack on the "Masculine State", the "Government of Men", and unjust "Law" (often referred to by the suffragists, like the anarchists before them, as a proper noun). Are suffragists drawing upon an earlier anarchist socialist tradition when they describe laws made by men as unnatural impediments to the free and robust evolution of society? Does their vision of a "Parliament of Mothers" and the "reconstitution of the State" suggest a more radical goal than merely the next step in the British democratization process begun in I832? Did suffrage militancy and hunger strikes (a tactic first introduced by Fabian Women's Group member Marion Wallace Dunlop) represent for some women a continuation of the revolutionary tradition, and particularly the tactic of "propaganda by the deed"? Alongside

8I. Fabian Women's Group Executive Committee, The National Insurance Bill: A Criticism (London, I9I I), pp. 9, 25-26. See also Fabian Women's Group Executive Committee, How the National Insurance Bill Affects Women (London, I9I2); the report of Wilson's lecture to the Fabian Society on "The Economic Disintegration of the Family," in Fabian News (July 1909); the interview with Wilson in "Maternity Benefits: Irregular Unions and Their Penalty", The Standard (3 and 7 November i9i I).

82. For recent re-evaluations of the suffrage movement see Laura E. Nym Mayhall, The Militant Suffrage Movement: Citizenship and Resistance in Britain, I860-1930 (Oxford [etc.], 2003); Sheila Rowbotham, Dreamers of a New Day: Women Who Invented the Twentieth Century (London [etc.], 2010). For one of the best treatments of the contradictory arguments and mixed meanings within the movement, see Lisa Tickner, The Spectacle of Women: Imagery of the Suffrage Campaign 1907-I4 (Chicago, IL [etc.], I988). 
the chauvinism and imperial hubris that marks almost all pre-war social and political movements, is there a cosmopolitan current drawn from the utopian democratic tradition resonating as well in the suffragists' dreams? Pursuit of these questions might cast a different light on the words of Carrie Chapman Catt, speaking to an international gathering of women in I909. "Though diligently and persistently we work each in our own land", she explained, the "Cause",

[...] has lifted us above the sordid struggle of each nation. [...] We have been baptized in that spirit of the Twentieth Century which the world calls Internationalism.[...] Our task will not be fulfilled until the women of the world have been rescued from those discriminations and injustices which in every land are visited upon them by law and custom. ${ }^{83}$

Certainly, the press, politicians and general public made such a connection between the women's movement and an earlier revolutionary tradition, as the suffragists were frequently described as "terrorists" and "anarchists" and their politics described as "suffragette outrage". Writing his memoirs in I9I 2, H.M. Hyndman drew explicit connections between the "downright Anarchism" of the suffrage movement and the anti-state branch of the socialist revival of the 1880 s. $^{84}$ The veteran Fabian Edward Pease too recognized an earlier, no longer dominant vision of socialist politics in suffrage activism, a movement he described as a "revival of oldfashioned anarchism in a new form". 85

The conventional narrative that tells a story of suffrage victory looks problematic once these links to an earlier radical tradition are considered. Like most democratic uprisings, the women's movement failed, ended abruptly by the very war between "Masculine States" that the women believed they could prevent if they had the vote. From Wilson's and other socialist women's perspectives, the bestowal of a limited franchise in I9I 8 as a reward for cooperation in war-making was no victory. Although the inclusion of women in the electorate soon became a global mark of state legitimacy, it did not lead to the "reconstituted state" that they had imagined.

Wilson's political activism ended with World War I. In reflecting on his own withdrawal from political activism, Wilson's former Fabian colleague Graham Wallas expressed disappointment that the word socialism had lost its revolutionary meaning, a regret that Wilson might well have shared. It might again express emancipation some day, he reflected. "Or, as I myself think it to be more probable, the word socialism may go the

83. International Women's Suffrage Alliance, Report of the Fifth Conference (1909), in the Fawcett Library Collection, now The Women's Library at London Metropolitan University. 84. H.M. Hyndman, Further Reminiscences (London, I912), pp. $295-296$.

85. Edward Pease, The History of the Fabian Society (London, I916, 1963), p. 229. 
way of 'natural rights' and the 'greatest happiness principle,' and in our new need we may find a new name for our hopes."

Wilson's search for a language to express her vision of the democratic ideal took her on a non-linear excursion through radical causes and set her shoulder to shoulder with activists who were often drawn to these "gravitational fields" by very different forces. Their attempts to find a common language and to act politically offer not only new ways to look at the belle époque, but also historically grounded ways to think about similar attempts in today's global radical networks.

86. Graham Wallas, "Socialism and the Fabian Society" (г916), in May Wallas (ed.), Men and Ideas (London, 1940). 